\title{
Public acceptance of the use of reclaimed water for the irrigation of vineyards: a case study in Guadalupe Valley, Mexico
}

\author{
L. G. Mendoza-Espinosa ${ }^{1}$, D. Acosta-Zamorano ${ }^{1}$, \\ N. Calderón de la Barca $^{2}$ \& A. Cabello-Pasini ${ }^{1}$ \\ ${ }^{1}$ Oceanographic Research Institute, \\ Autonomous University of Baja California, Mexico \\ ${ }^{2}$ School of Management and Social Sciences, \\ Autonomous University of Baja California, Mexico
}

\begin{abstract}
For recent decades, and due to water shortages and droughts, reclaimed water has been more frequently used for the irrigation of crops. The Guadalupe Valley, located in the north-western region of Mexico, is a region that produces approximately $90 \%$ of the wine in the country. The region is semiarid and in need of new sources of water for public and agricultural use. Reclaimed urban wastewater has been identified as a possible source of water for vineyard irrigation. Therefore, a survey was conducted to identify the degree of public acceptance of wine consumers and winemakers into using reclaimed water for irrigation. It was found that $80 \%$ of the public were in favor of consuming wine produced with vines irrigated with reclaimed water, despite the fact that the majority were not aware that in other places of the world and the country, reclaimed water is used for irrigation. On the other hand, $80 \%$ of the grape growers and winemakers that were interviewed recognized the potential of using reclaimed water for the irrigation of their vineyards yet called for the adequate operation of the wastewater treatment plants and proper supervision by a trustworthy thirdparty. The rest of the grape producers did not favor the use of wastewater due to concerns of the possible high costs of reclaimed water (although no information of these costs were provided) and the potential rejection of wine consumers, especially by consumers outside Mexico.
\end{abstract}

Keywords: reclaimed water, agriculture irrigation, wine production, water shortage. 


\section{Introduction}

In recent years the modification of land use in most parts of the world and the resources exploitation from natural ecosystems has caused its degradation without precedent in the history of mankind [1]. This type of development has, in many cases, produced environmental global effects such as the emission of greenhouse gases, the destruction of the ozone layer, air pollution, etc. [2]. At the local level it has caused soil erosion, loss of biodiversity, degradation of water quality, etc.

The new tendencies in environmental research recommend participation of the academia with a degree of social compromise. Participation of the society in the elaboration of environmental diagnosis generates political responsibility by helping resolve disputes, provide a certain degree of transparency to the decisions, which means greater acceptance by the general public, causes a decrease in errors and corruption and strengthens institutions [2].

Until recently, water has been considered as a non-limited resource. However, the increase in its demand in many cases above its availability has been a growing problem, which has forced to manage water in a more efficient way. It has been estimated that in the next 50 years, $40 \%$ of the world population will be living in areas with water scarcity or hydric deficit [3]. The growing competition between urban and agriculture users will intensify, particularly in arid and semiarid regions where clean water will be scarce [3].

The use of reclaimed water for the irrigation of crops has increased in the last decades as a result of water scarcity in many regions of the world [4]. Studies on the use of reclaimed water in agriculture include, among many others, the irrigation of maize [5] where a $60 \%$ increase in productivity was reached, vines [6] and hydroponic cucumber [7].

In Mexico, like the rest of the word, agriculture uses most of the available water $(71 \%)$ followed by urban use (20\%) and industry (6\%) [8]. Mexico continues to be a country with a high agriculture production. Most of the agricultural water demand has to be met by means of surface or groundwater as rainfall is limited. Irrigated agriculture represents $54 \%$ of the total national production and $70 \%$ of the produce for exportation. However, $35 \%$ of the water used for irrigation is lost due to water leaks and evaporation [9].

The use of reclaimed water for irrigation has only been considered as an integrated part of water managing schemes in the past 30 years [3] and its use has increased in the last 20 years as a result of the increase in water scarcity and facilitated by new regulations and water management policies. It has been favored mainly in arid and semiarid regions. According to FAO [3] agriculture is the main user of reclaimed water and $10 \%$ of all agricultural land (approximately 20 million hectares) is irrigated with reclaimed water in 50 countries. However, only approximately 525,000 hectares of these are irrigated with treated wastewater, as the great majority is irrigated with untreated wastewater [10]. In Mexico, reclaimed water (mostly untreated wastewater) is used for the irrigation of crops in places such as the Mezquital valley, Guanajuato and Durango [3]. In all cases farmers are benefited by the nutrient content of the reclaimed water and the cities dispose adequately of the wastewater they produce. 
The Guadalupe valley, located approximately $30 \mathrm{~km}$ northeast of the city of Ensenada, in the Baja California peninsula is a region (Figure 1) where precipitation is on average $250 \mathrm{~mm} / \mathrm{y}$ [11]. The valley supports the production of approximately $90 \%$ of the wine produced in Mexico [11] and in the last decade the number of small wineries has increased significantly. This, in addition to the lack of rain, has exasperated water availability of the local aquifer. The most recent national census [12] establishes that the Guadalupe aquifer has an average yearly recharge of $26.4 \mathrm{Mm}^{3}$, a natural discharge of $1.4 \mathrm{Mm}^{3}$, with a designated (allowed for) extraction of $37.04 \mathrm{Mm}^{3}$ resulting in a deficit of $12.04 \mathrm{Mm}^{3}$.
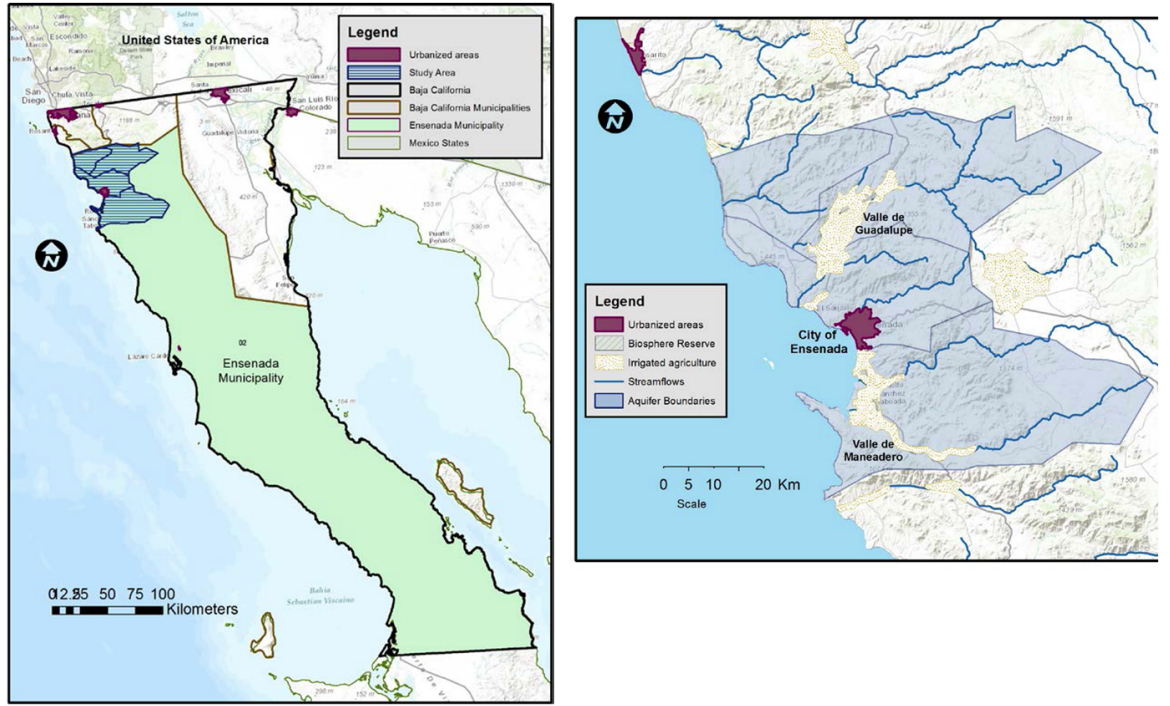

Figure 1: The Ensenada municipality, the city of Ensenada and Guadalupe Valley location (Source: Medellin-Azuara et al. [29]).

The city of Ensenada produces approximately 650 liters per second (lps) of secondary effluent through its four wastewater treatment plants. Wastewater receives secondary treatment and has the potential to reach the "Title 22 benchmark" which is the benchmark for unrestricted irrigation [3]. Wastewater in Ensenada does comply with the treatment recommended [4] for the irrigation of vineyards, which consists in secondary treatment followed by disinfection.

The closest wastewater treatment plant to the Guadalupe valley is called El Sauzal and has a capacity of treating $60 \mathrm{lps}$. Previous studies demonstrated that the water quality from the El Sauzal wastewater treatment plant is good enough to be an alternative for the irrigation of vineyards $[6,13,14]$.

Therefore, the use of reclaimed water has the potential for being suitable for the irrigation of vineyards in the Guadalupe valley. According to Hartley [15] to ensure public confidence and an effective decision-making process in water reuse it is necessary to: 1) make available favorable managing information for all stakeholders, 2) demonstrate organizational commitment to maintain individual 
motivation, 3) ensure a fair and sound decision-making process and outcome by promoting communication and public dialogue, and 4) build and maintain public trust. If reclaimed water is to be used for the irrigation of wines in the Guadalupe valley it is of critical importance to know the response of wine consumers and wine producers regarding such a procedure in accordance to maintaining public trust. Hence, the objective of the present study was to evaluate the perception of the consumers and wine producers regarding the consumption of wine produced with grapes irrigated with reclaimed water in the Guadalupe valley.

\section{Methodology}

This research was conducted in the field of public perception on environmental issues. According to Padilla-Sotelo and Luna [16] this will usually depend on the way each individual appreciates and values its own environment and supplies elements that can contribute towards conservation.

In order to evaluate the perception of the public related to the use of reclaimed water for vine irrigation, two techniques of social research were used: the interview and the survey. The survey was applied to the general public that attended a place representative of the local wine culture, the Wine Museum (Museo del Vino) at the Guadalupe Valley. The poll was applied to one hundred twenty people over 18 years old that attended the museum between August and December 2012. The survey included information about the characteristic of the participant such as age, education, etc. and on the other hand general knowledge about water issues of the city of Ensenada and the Guadalupe valley. The poll instrument was previously adjusted through a series of pilot tests before its application.

In contrast, an interview was used to obtain information from winemakers of the Guadalupe Valley regarding their perception of the use of recycled wastewater for the irrigation of their vines. Fifteen interviews were undertaken with a series of open questions in order to evaluate the winemakers point of view related to the challenges for wine production in the valley, the apparent value of water and its opinion about the use of reclaimed water for irrigation. The interviews were undertaken from August 2012 to June 2013.

Results from the instruments were analyzed with the software SPSS 15.0 (SPSS, 2011) to obtain frequency and tendencies between variables.

\section{Results and discussion}

\subsection{General public survey}

Fifty one per cent of the people knew about the sources of water that supply the city of Ensenada. Regarding water sources for the Guadalupe valley, $46 \%$ of those polled knew about the sources while $54 \%$ did not know. However, when asked to name the sources of water for both city of Ensenada and Guadalupe valley, only 
$20 \%$ knew correctly for the city and $46 \%$ for the valley. Forty seven per cent of those polled are aware that there is a water shortage problem in the city of Ensenada, mainly through articles in newspapers. In regards of the awareness of water shortages in the Guadalupe valley, $39 \%$ of those polled said that they were aware of the problem, $26 \%$ said there was no problem and $35 \%$ did not know that there were water shortages.

There are several examples worldwide in which reclaimed water has been used for the irrigation of crops. In Tunisia, for example, approximately $30-40 \%$ of the recollected wastewater is used for the irrigation of fodder, cereals, vineyards, citric and fruit trees [18]. In Israel, since 1965 national norms have allowed secondary effluent to be used for the irrigation of crops with the exception of produce that is consumed raw [19]. Furthermore, in Saudi Arabia reclaimed water has been used for crops irrigation, landscape and gardens irrigation, and other uses [20]. Finally, in central Mexico, wastewater from Mexico City is used for the irrigation of 90,000 ha of farmland of which $42 \%$ is alfalfa, $39 \%$ maize, $7 \%$ grass, $2 \%$ oats and produce [3].

Results found in this study indicate that $80 \%$ of those polled were unaware of the use of reclaimed water for the irrigation of crops. Yet when asked if they would consume wine whose grapes would have been irrigated with reclaimed water $87 \%$ answered positively, which is encouraging.

Fifty three per cent of those polled consume 1-2 bottles of wine per month, $33 \% 1-2$ bottled per week while $28 \%$ only consumed 1 or 2 bottles of wine per year. Ninety two per cent of people between 20 and 30 years of age indicated that they would buy wine produced with grapes irrigated with treated wastewater while only $78 \%$ of people between $41-50$ years of age would buy this wine. In relation to the factors that influence the selection of wine and the knowledge about using reclaimed water for the irrigation of vines, all of those who favored the year of production of the wine accepted such measure, followed by those who base their selection on the brand (92\%) and $90 \%$ on the place of origin of the wine.

Perception about the use of wastewater as an alternative for vine irrigation varied depending on the professional background. Ninety six percent of the interviewed working in the area of natural and health sciences agreed to such measure claiming that it would be environmentally friendly and it would represent a better management of water, a critically important resource in the region. Similarly, ninety one per cent of university students were in favor of the use of reclaimed water for irrigating vines. Approximately $85 \%$ of the interviewed people working on the social and administration sciences considered that the irrigation of vines with reclaimed wastewater was a good idea only $71 \%$ of those with an engineering background were in favor.

Of the several factors that influence consumer decision in relation to the purchase and consumption of wine, the terroir of the wine is one of the most important. In the present study $26 \%$ of the those surveyed mentioned that the terroir was the most important factor when choosing a wine, $24 \%$ preferred to choose a local wine, $20 \%$ made their decision based on type of grape, $11 \%$ on brand, $7.5 \%$ on price and $6 \%$ take into account flavor and year of bottled. 
Reclaimed water can be used efficiently in substitution for potable water for many activities. However, it is extremely important to meet a series of requirements in order to decrease the risk for human population and the environment. First of all, a certain degree of water quality must be reached. The level of treatment will depend on the activity in which the reclaimed water will be reused and the degree of perception of risk by the population [22]. Misinformation is also a factor that affects the acceptance or not of reclaimed water for irrigation. Higgins et al. [21] mentioned that the use of reclaimed water is not as widespread as it should due to prevalent concerns about its impact on public health. Moreover, media has a strong influence on the way a community perceives the risk of water reclamation uses and context is crucial to understanding the stated willingness of the public to adopt water reuse or recycling [24]. According to Leong [23], public acceptance of reclaimed water will depend in great measure on the information that the public has on water availability in the area of study. They found a correlation between media coverage on water reuse projects and water reclamation acceptance in Singapore and Australia. In Singapore, positive media coverage helped the people accept water reclamation projects; on the other hand, negative media coverage in Australia caused its rejection.

In the present study $68 \%$ of those surveyed mentioned that they did not know about the existence of wastewater treatment plants in the city of Ensenada; only $32 \%$ knew about their existence. However, of those that responded that they knew about the existence of wastewater treatment plants, $16 \%$ said that the treatment was good, $15 \%$ regular and $1 \%$ bad.

People from abroad (Chile, Ecuador, Spain, France, Panama and Peru) but living or visiting Mexico were in favor of the use of reclaimed water (93\%). People from Northern Mexico responded in favor in $91 \%$ of the cases while people from Central Mexico and South of the country were in favor in $81 \%$ and $80 \%$, respectively. Bautista et al. [2] concluded that the perception of environmental problems by individuals, there is a geographic bias due to their knowledge of their own surroundings. In the case of the Guadalupe valley, people from Ensenada are more aware of the water problem than, for example, people from central or southern Mexico. Tellingly, visitor from other countries were in favor of the use of reclaimed water perhaps because they are informed about such practice within their own countries.

\subsection{Wine producers}

Seventy per cent of the wine producers had more than 10 years of in the wine business, while $30 \%$ had between 5 and 10 years' experience. Some producers considered their activity as a "hobby" and others as a family tradition, yet the majority considers it an activity with a great degree of uncertainty. They considered that the main challenges lying ahead for the development of wine production in the Guadalupe valley are: the competition from wine producers from other countries, the high taxes that have to be paid by local producers and most important, water availability. All producers are well aware that water is of prime concern due to the fact that the Guadalupe valley is located in a semiarid region. 
They recognize that they do not have the solutions for solving the water shortage in the region. They considered that the responsibility for solving the water problem in the area lye in the local, state or federal government.

All wine producers know that wastewater is treated in the city of Ensenada yet they do not know the level of treatment and, hence, the resulting quality of the reclaimed water. They distrust the water quality information provided by the municipal wastewater treatment operator but they are aware that the great majority of the treated water (95\%) is being discharged to the ocean and only 5\% is used for the irrigation of gardens and other green areas.

Reclaimed water has proven to be safe for the irrigation of crops. Previous studies [25] that evaluated the effect of the use of reclaimed water for the irrigation of field crops in Spain, concluded that crops showed better growth due to the presence of nutrients in larger quantities in the reclaimed water. Studies [26] on the effect of reclaimed water on the production of tomatoes and other fruits in Sicily, Italy and reported very low risks of bacterial contamination with proper handling thus suggesting the viability of reclaimed water for the irrigation of tomatoes. Cirelli et al. [26] conclude that under controlled conditions, low-quality treated wastewater can be used as an additional water resource to increase vegetable production in water-scarce Mediterranean environments.

A study by Umaña [5] concludes that farmers' perception about the use of reclaimed water for the irrigation of maize is varied. They identify as main advantages the increase yields obtained, a decrease in the use of fertilizers, the use of land that otherwise would be idle and the decrease of pollution of natural water resources. However, the main disadvantages are bad odors, lack of experience of handling the reclaimed water and possible reticence by product consumers. Therefore, it is suggested to include workshops for farmers and consumers to inform about the pros and cons of the use of reclaimed water for crops irrigation.

Tellingly, $100 \%$ of those interviewed are aware that reclaimed water is being reused is common in certain places. Eighty per cent mentioned that they are in favor of reclaimed water reuse but $20 \%$ would not consider using reclaimed water for irrigation. Their main concern is the high costs of reclaimed water (although no information of these costs were provided) and the rejection of wine consumers, especially in consumers outside Mexico. Of those that accept using reclaimed water for the irrigation of their vineyards they would require water quality assurance from a third party (like a university laboratory) to be completely sure about the quality of the reclaimed water. This is in agreement with the National Research Council (2012) [27], that mentions that local independent (e.g., university) scientists are viewed by the public as the most credible sources of information on reclaimed water. Likewise, Leong [23] highlighted that among those who oppose water reuse, there are those who adopt their point of view based on an inadequate (or erroneous) understanding of the science behind water recycling. A third party (in this case, the university) could help overcome such opposition. 


\subsection{Overall discussion}

Although concentrating on greywater, Doménech and Saurí [28] evaluated the perception of people on reclaimed water and its effect on public health. People tend to be wary about the robustness of wastewater treatment plants, yet they tend to favor the idea due to its positive effect on the environment. They also highlight the fact that a society vulnerable to water shortages is probably more receptive to strategies aimed at minimizing this problem. This might be the case for the people interviewed and definitely for the wine producers. Water shortages are more and more common for city residents and have a great impact on their perception on water problems for the city.

The goal for the integrated administration of water within the EnsenadaGuadalupe region is the acceptance of the farmers for using reclaimed water for the irrigation of their produce. If this is accepted, the ultimate goal would be, as in most places where this is taking place [3], to allow for the exchange of water rights between users, in this case the farmers and the urban users (city of Ensenada). In certain places in Spain and in Mexico (the state of Durango) water interchange between farmers and cities is feasible as has been demonstrated to work. Farmers could be persuaded by means of interchanging their water rights with reclaimed water with a guaranteed concentration of nutrients that can be used for crops irrigation [3]. However, In Ensenada this would represent another challenge as farmers would like to have several sources of water as a way to avoid droughts and not surrender their water rights. Yet, as Becerra et al. [9] mention, if water rights in Mexico would be assigned depending on water markets, it would be very difficult for farmers to keep their water rights when urban users demand the scarce resource. In their study, they found a positive correlation between conflict and increase in water tariffs. However, it is necessary to make reforms to the legal and political framework of water to allow for water prices adjustments and the establishment of water markets.

Users' knowledge constantly changes, as do public perception and practices [28]. Therefore, the present study provides an insight into the level of acceptance of consumers and wine makers in the Guadalupe Valley and provides with a valuable initial point. This acceptance can change in favor or against depending on water management decisions by the local water authorities and by water availability.

\section{Conclusions}

In the Guadalupe valley, were water shortage is common that can lead to the use of water reclamation for irrigation, public acceptance is of main concern. There is an $80 \%$ acceptance by those who were polled to the consumption of wine produced with vines irrigated with reclaimed water, even without knowing the type of treatment that the wastewater receives and without knowing that in other places of the world and the country reclaimed water is used for irrigation. Eighty per cent of the winemakers that were interviewed recognized the potential of using 
reclaimed water for the irrigation of their vineyards with an adequate operation of the wastewater treatment plants and proper supervision by a worth trusty thirdparty.

\section{References}

[1] Leff, E. \& J. Carabias. 1993. Cultura y manejo sustentable de los recursos naturales. México: UNAM/Porrúa/Programa de Naciones Unidas para el Medio Ambiente.

[2] Bautista, F., Balancán, Z. A. M., Navarro, A. J., Bocco, G. 2011. Percepción social de los problemas ambientales en Yucatán, México. Una visión desde la geografía. Teoría y Praxis. 9: 33-54.

[3] FAO. 2013. Reutilización de agua en la agricultura: Beneficios para todos. Informe sobre temas hídrico. Organización de las Naciones Unidas para la Alimentación y la Agricultura. Roma.

[4] Crook J. \& Lazarova, V. (2005). International health guidelines and regulations. In: Lazarova, V. \& Bahri A. (eds.) 2005. Water Reuse for Irrigation. Agriculture, landscapes and Turf Grass. CRC Publisher. 61-81, $408 \mathrm{pp}$.

[5] Umaña, G. E. 2007. El reuso de aguas residuales para riego en un cultivo de maíz (Zea mays L.) una alternativa ambiental y productiva. La Calera. Universidad Nacional Agraria. 6(7): 22-26.

[6] Mendoza-Espinosa, L. G., Cabello-Pasini, A., Macias-Carranza, V., Daesslé, L. W., Orozco-Borbón, M. V. and Quintanilla, A. 2008. The effect of reclaimed wastewater on the quality and growth of grapevines. Water Science \& Technology 57(9): 1445-1450.

[7] Morillo, G., Monsalve, R., Mendoza, J., Isea, D., Araujo, I., Vargas, L. And Angulo, N. 2009. Chemical and microbiological evaluation of cucumber (Cucumis sati vus L.) using wastewaters irrigation. Rev. Téc. Ing. Univ. Zulia. 32(1): 68-76.

[8] CONAGUA, 2012. Programa Nacional Hídrico 2007-2012. Gobierno Federal. SEMARNAT.

[9] Becerra, P. M., Sáinz, S. J., Muñoz, P. C., 2006. Los conflictos por agua en México. Diagnóstico y análisis. Gestión y política pública. XV/1: 111-143.

[10] Jiménez, B. \& Asano, T. (eds.) 2008. Water Reuse: An International Survey of Current Practice, Issues and Needs. IWA Publishing, London, 628 pp.

[11] Daesslé, L. W., Mendoza-Espinosa, L. G., Camacho-Ibar, V. F., Rozier, W., Morton, O., Van Dorso, L., Lugo-Ibarra, K. C., Quintanilla-Montoya, A. L. \& Rodríguez-Pinal, A. 2006. The hydrogeochemistry of a heavily used aquifer in the Mexican wine-producing Guadalupe Valley, Baja California. Environmental Geology 51: 151-159.

[12] Comision Nacional del Agua (CONAGUA), 2009a. Actualización de la Disponibilidad Media Anual de Agua Subterránea Acuífero (0207) Guadalupe, Estado de Baja California, Diario Oficial de la Federación. Publicada 28 Agosto 2009. Comision Nacional del Agua: Mexico, D.F. 
[13] Acosta-Zamorano, D., Macías-Carranza, V., Mendoza-Espinosa, L. G., Cabello-Pasini, A. (2013). Efecto de las Aguas Residuales Tratadas sobre el Crecimiento, Fotosíntesis y Rendimiento en Vides (Vitis vinífera) Tempranillo en Baja California, México. Agrociencia, 47(6), 753-766.

[14] Acosta-Zamorano, D., Macías-Carranza, V., Mendoza-Espinosa, L. G., Cabello-Pasini, A. (2013) Efecto del agua residual ratada sobre la madurez de la uva (Vitis vinífera var. Tempranillo) en Baja California, México. Agrociencia, 47(6), 767-779.

[15] Hartley T.W., (2006). Public perception and participation in water reuse. Desalination, vol. 187, 115-126.

[16] Padilla-Sotelo L. S., Luna, M. 2003. Percepción y conocimiento ambiental en la costa de Quintana Roo: una caracterización a través de encuestas. Investigaciones Geográficas, Boletín número 52, UNAM, Distrito Federal, pp. 99-116.

[17] Bahri, A. 2009. Managing the other side of the water cycle: making wastewater an asset. TEC Background Paper No. 13. Global Water Partnership, Stockholm.

[18] Shelef, G., Azov. Y., Kanarek. A., Zac. G. y Shaw. A., 1994. The Dan region sewerage wastewater treatment and reclamation scheme. Water Science and Technology. Vol. 30(9): 229/238.

[19] Al-Zubari K. (1997). Towards the Establishment of a Total Water Cycle Management and Reuse Program in the GCC Countries. Desalination, vol. 120, no. 1-2, 3-14.

[20] Seguí-Amórtegui, L. A., 2004. Sistemas de Regeneración y Reutilización de Aguas Residuales. Tesis doctoral. Departamento de ingeniería agroalimentaria y biotecnología. Universidad Politécnica de Cataluña. Barcelona, España.

[21] Higgins, J., Warnken, J., Sherman, P.P., Teasdale, P.R., 2002. Surveys if users and providers of recycled water: quality concerns and directions for applied research. Water Research, 36: 5045-5056.

[22] Dolnicar, S., y Schòfer, I. A., 2009. Desalinated versus recycled water: Public perceptions and profiles of the accepters. Journal of Environmental Management, 90: 888-900.

[23] Leong C. (2010). Eliminating 'yuck': a simple exposition of media and social change in water reuse policies. Water Resources Development, vol. 26, no. 1, 113-126.

[24] Mañas-Ramírez et al. 2002 Invest. Agr.: Prod. Prot. Veg. Vol. 17(1).

[25] Aiello, R., Luigi, C. G. and Consoli, S. 2007. Effects of reclaimed wastewater irrigation on soil and tomato fruits: A case study in Sicily (Italy). Agricultural water management 93: 65-72.

[26] Cirelli GL, Consoli S, Licciardello F, Aiello R, Giuffrida F \& Leonardi C. (2012). Treated municipal wastewater reuse in vegetable production. Agricultural Water Management, vol. 104, 163-170.

[27] National Research Council, (2012). Water Reuse: Potential for Expanding the Nation's Water Supply through Reuse of Municipal Wastewater. The 
National Academies Press, Washington, D. C., ISBN 978-0-309-25749-7, $262 \mathrm{pp}$.

[28] Doménech, L., Saurí, D. 2010. Socio-Technical Transitions in Water Scarcity Contexts: Public Acceptance of Greywater Reuse Technologies in the Metropolitan Area of Barcelona. Resour., Conserv., Recycl. 55: 53-62.

[29] Medellin-Azuara, J., Mendoza-Espinosa, L.G. Pells, C. M. and J.R. Lund (2013). Pre-Feasibility Assessment of a Water Fund for the Ensenada Region: Infrastructure and Stakeholder Analyses. A Report for the Nature Conservancy. Prepared by the Centre for Watershed Sciences, UC Davis. 